\title{
VLIV HUSTOTY DŘEVA NA NAMĚŘENÉ HODNOTY PŘI PRÁCI S KUČEROVOU VRTAČKOU
}

\author{
INFLUENCE OF WOOD DENSITY ON MEASURED VALUES WHEN \\ WORKING WITH A KUČERA`S DRILL
}

\author{
Pavel Černý,
}

*166889@vutbr.cz

${ }^{1}$ Vysoké učení technické v Brně, Fakulta stavební, Veveří 331/95, 60200 Brno

\begin{abstract}
Abstrakt
Diagnostika dřevěných konstrukcí je ve stavebnictví stále hojně využívaným oborem. Naměřené hodnoty při testování v rámci diagnostiky dřeva jsou vždy ovlivněny vlastnostmi dřeva. Jednu z nejvýznamnějších rolí u diagnostiky dřeva představuje vlhkost, která ovlivňuje široké spektrum fyzikálně mechanických vlastností. Jinak tomu nebylo i při testování Kučerovou vrtačkou, která je standardně využívána pro diagnostiku zdiva. Pro účely výzkumu musela být vrtačka transformována pro použití na dřevěné konstrukce. Transformace byla provedena na základě speciální redukce.
\end{abstract}

\section{Klíčová slova}

Diagnostika dřeva, Kučerova vrtačka, hustota dřeva, vlhkost dřeva, vlastnosti dřeva

\begin{abstract}
Diagnostics of wooden structures is still a widely used field in construction. The measured values during testing in wood diagnostics are always influenced by the properties of the wood. One of the most important roles in wood diagnostics is moisture, which affects a wide range of physical and mechanical properties. This was not the case when testing with the Kučera's drill, which is standardly used for masonry diagnostics. For research purposes, the drill had to be transformed for use on wooden structures. The transformation was performed on the basis of a special reduction.
\end{abstract}

Key words

Wood diagnostics, Kučera`s drill, wood density, wood moisture, wood properties

\section{1 ÚVOD}

Dřevěné konstrukce byly velmi často využívány v historických budovách, u kterých je nutný velmi šetrný postup při diagnostice konstrukce. Je tedy vyžadován co nejšetrnější zásah do konstrukce, proto jsou využívány diagnostické metody, které nepoškozují zásadně konstrukci. Aby nedošlo k poškození dřevěné konstrukce, je v současné době využíváno několika moderních diagnostických metod, které mohou zjistit druh a rozsah skrytého poškození. Skryté poškození může být v dřevěné konstrukci způsobeno vlivem živých organismů - dřevokazným hmyzem nebo dřevokaznými houbami [1].

V moderní diagnostice jsou známé tři skupiny metod, které výrazně ovlivňuji zasažení do stávající konstrukce. Mnoho moderních diagnostických přístrojů umožní přesně získat potřebné informace z konstrukce dřeva. Mezi skupinu metod patři následující:

- Nedestruktivní (neinvazivní) diagnostické metody.

- Semi-destruktivní (částečně invazivní) diagnostické metody.

- Destruktivní (invazivní) diagnostické metody [2].

Mezi zcela neinvazivní diagnostické metody je možné zařadit vizuální posouzení, měření vlhkosti dřeva, měření rychlosti šíření ultrazvukových vln, radiační metody a také radiometrii. Právě zmíněná vlhkost dokáže velmi ovlivnit různé vlastnosti dřeva a je nutné se vlhkostí při diagnostice dřeva zabývat. Mezi částečně invazivní diagnostické metody patří odporové zarážení trnu pomocí Pilodynu, odporové mikrovrtání, odporové zatlačování trnu, vytahování vrutu, zkoušení radiálních vývrtů, zkoušení tahových mikrovzorků, hodnocení stavu podle pilin, 
endoskopie a třeba bude reálné jednou zařadit i metodu pomocí Kučerovy vrtačky, na kterou je cílen tento výzkum [3].

Kučerova vrtačka je v běžné praxi využívána pro diagnostiku pevnosti malt. Je zde předpoklad, že by tato metoda mohla vhodně diagnostikovat i dřevěné konstrukce. Výsledky mohou být ovlivněny způsobem nasycení dřeva vodou, které bylo odlišné oproti dřívějším studiím. Cílem práce je prohloubení naměřených výsledků při použití Kučerovy vrtačky pro dřevěné konstrukce. Článek se zabývá hustotou dřeva a jejím ovlivněním v dosažených výsledcích.

\section{VLIV VLHKOSTI NA VLASTNOSTI DŘEVA}

Dřevo je hygroskopický materiál, který je ovlivněn vlhkostí. Vlhkost z okolí přijímá nebo naopak odevzdává. Na základě př́imého kontaktu s vlhkostí okolního prostředí se mění samovolně vlhkost dřeva. Vlhkost má na vlastnosti dřeva spíše negativní účinky na fyzikální a mechanické vlastnosti. Vlhkost je vyjádřena poměrem mezi hmotností vody ve dřevě a hmotností vysušeného dřeva [4].

Důležitou vlastností pro výzkum je hustota, který je ovlivněna ve velké míře vlhkostí. Je známo, že se zvyšující hustotou, dochází ke zvyšování vlhkosti. Vlhkost tedy prokazatelně zvyšuje hmotnost a objem tělesa, kdy tyto dva prvky jsou podstatně pro vypočítání hustoty. Hustota je různá při různých vlhkost. Hustota je vypočtena z uvedeného vzorce:

$$
\rho_{\omega}=\frac{m_{\omega}}{V_{\omega}}\left[\mathrm{kg} / \mathrm{m}^{3}\right],
$$

kde $\rho_{\omega}-$ hustota dřeva při dané vlhkosti $\left[\mathrm{kg} / \mathrm{m}_{3}\right], m_{\omega}-$ hmotnost dřeva při dané vlhkosti $[\mathrm{kg}], V_{\omega}-$ objem dřeva při dané vlhkosti $\left[\mathrm{m}_{3}\right]$.

Jsou rozlišovány 3 druhy hustoty:

- hustota suchého dřeva,

- hustota vlhkého dřeva,

- hustota dřeva při $12 \%$ vlhkosti.

Na základě hustoty jsou děleny také dřeviny:

- dřeva s nízkou hustotou,

- dřeva se střední hustotou,

- dřeva s vysokou hustotou [5].

Vlhkost dále ovlivňuje tyto vlastnosti: objemové změny (bobtnání a sesychání), pevnosti, modul pružnosti a trvanlivost. Ve výzkumu byla také brána rozdílná vlhkost, která byla určena před začátkem měření a byla stanovena vždy na přesnou hodnotu. Hodnota vlhkosti byla $7 \%$. Vlhkost byla stanovena váhovou metodou dle normy ČSN EN 13183-1. Získání požadované vlhkostí vzorků bylo dosaženo pomocí klimakomory, jejichž uložení je patrné v Obr. 1 .

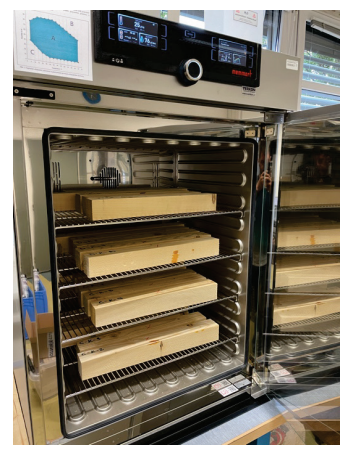

Obr. 1 Dřevěné vzorky uložené v klimakomoře. 


\section{METODIKA}

Primárním cílem výzkumu byla transformace Kučerovy vrtačky, která je v běžné praxi využívána pro stanovení pevnosti malt. Kučerova vrtačka byla vyrobena ve dvou verzích:

- ruční Kučerova vrtačka,

- $\quad$ elektrická Kučerova vrtačky.

Obě verze Kučerovy vrtačky byly sestaveny na technickém zkušebním ústavě stavebním v Praze a jedná se o speciálně upravenou vrtačku. Pro projekt byla určena elektrická verze vrtačky, která je zobrazena na Obr. 2.

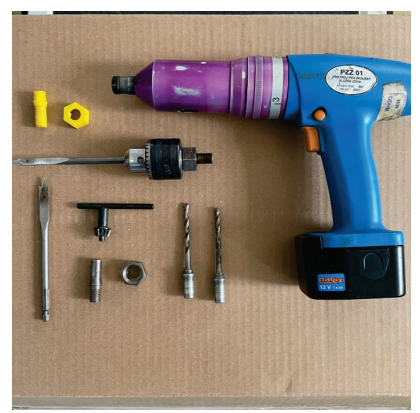

Obr. 2 Kučerova vrtačka s původními vrtáky a součástkami pro redukci.

Na celou transformaci Kučerovy vrtačky byl vytvořen projekt. Podle projektové dokumentace byla vyhotovena matice na dotažení redukce a část redukce, která zapadala do vrtačky. Na část redukce bylo našroubováno sklíčidlo. Této celkové přeměně se věnuje např́iklad článek [6].

Pro experiment bylo zvoleno smrkové dřevo, které je nejčastěji využíváno v dřevěných konstrukcích. Dřevo bylo bez zjevných vad a kazi̊. Rozměr zkušebních těles byl 58 x $58 \mathrm{~mm}$. Měřená délka zkušebních těles neměla pevně stanovenou hodnotu. Pro jednu vlhkostní třídu bylo použito 10 kusů zkušebních těles. Pro experiment byly dále zvoleny 2 vrtáky:

- plochý vrták o průměru $8 \mathrm{~mm}$,

- plochý vrták o průměru $10 \mathrm{~mm}$.

Tělesa před samotným testováním byla v sušárně vysušena do konstantní vlhkosti. Takto vysušená tělesa byla vložena do klimakomory, kde probíhalo rovnoměrné nasycení na požadovanou vlhkost. Vlhkost byla v průběhu nasycování kontrolována pomocí váhové metody. Pro stanovení hustoty byly po dosažení změřeny také rozměry vzorku a byla stanovena hustota dle př́slušného vzorce.

Na každém nasyceném zkušebním tělesu bylo následně provedeno 10 vrtů každým vrtákem, viz Obr. 3 . Vyvrtané otvory byly očištěny od přebytečných pilin a byla stanovena hloubka vrtu posuvným měřítkem, viz Obr. 4. Naměřené hodnoty byly zapsány a následně zprůměrovány v rámci jednoho zkušebního tělesa. Hodnoty průměrů hloubek vrtů a hodnoty hustoty jsou zapsány v Tab. 1.

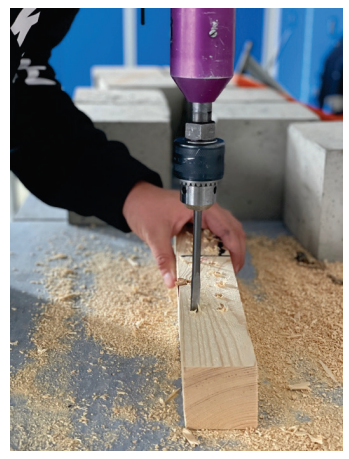

Obr. 3 Provedení vrtů.

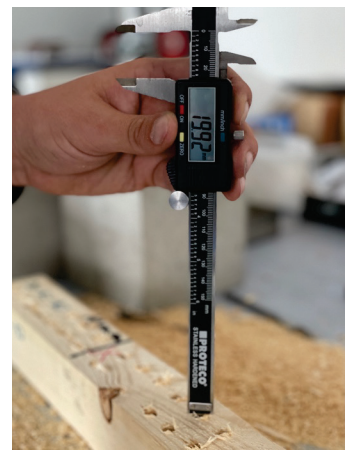

Obr. 4 Stanovení hloubky posuvným měřítkem. 


\section{VÝSLEDKY}

Naměřené hodnoty při 7\% vlhkosti zkušebních vzorků jsou zaznamenány v Tab. 1, kde jsou vypsány průměrné hodnoty vrtů plochými vrtáky a hodnoty vypočítané hustoty. Z tabulky je následně vytvořen graf, který hodnoty zobrazuje pro přehlednější zobrazení.

Tab. 1 Naměřené hodnoty vrtů a hustoty.

\begin{tabular}{cccc}
\hline $\begin{array}{c}\text { Označení } \\
\text { zkušebního tělesa }\end{array}$ & $\begin{array}{c}\boldsymbol{O} \text { hloubky vrtů vrtákem } \\
\text { s průměrem } \mathbf{8}[\mathbf{m m}]\end{array}$ & $\begin{array}{c}\boldsymbol{\emptyset} \text { hloubky vrtů vrtákem } \\
\text { s průměrem } \mathbf{1 0}[\mathbf{m m}]\end{array}$ & $\begin{array}{c}\text { Hustota tělesa } \boldsymbol{\rho}_{\mathbf{w}} \\
{\left[\mathbf{k g} / \mathbf{m}^{\mathbf{3}}\right]}\end{array}$ \\
\hline $\mathrm{A}-\mathrm{K}-1$ & 28,00 & 29,55 & 380,54 \\
$\mathrm{~A}-\mathrm{K}-2$ & 27,88 & 29,32 & 388,56 \\
$\mathrm{~A}-\mathrm{K}-3$ & 22,82 & 26,20 & 476,92 \\
$\mathrm{~A}-\mathrm{K}-4$ & 23,32 & 25,38 & 477,05 \\
$\mathrm{~A}-\mathrm{K}-5$ & 25,58 & 27,66 & 421,57 \\
$\mathrm{~A}-\mathrm{K}-6$ & 26,65 & 30,90 & 396,84 \\
$\mathrm{~A}-\mathrm{K}-7$ & 21,63 & 25,31 & 462,25 \\
$\mathrm{~A}-\mathrm{K}-8$ & 20,79 & 24,93 & 480,02 \\
$\mathrm{~A}-\mathrm{K}-9$ & 22,40 & 26,99 & 446,35 \\
$\mathrm{~A}-\mathrm{K}-10$ & 22,12 & 27,09 & 443,89 \\
\hline
\end{tabular}

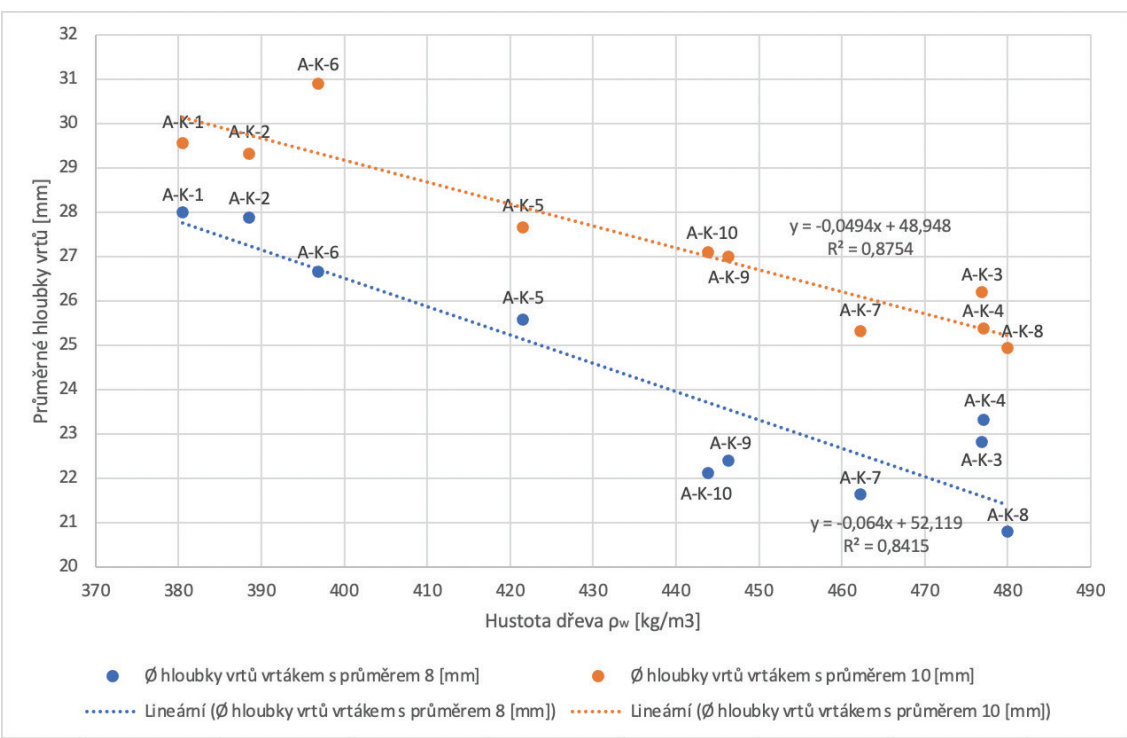

Obr. 5 Porovnání naměřených průměrných hloubek vrtů v závislosti na hustotě.

\section{DISKUZE}

Z naměřených hodnot je zřejmé, že hustota ovlivňovala výslednou hloubku vrtů. Vzorky byly vždy po dvojici z jednoho kusu dřeva (naprríklad A-K-1 a A-K-2 byly uříznuté z jednoho kusu dřeviny), proto měly být hloubky vrtů a hodnoty hustoty podobné. Tento fakt je průkazný v naměřených hodnotách, jediným rozdílem je dvojice A-K-5 a A-K-6. K uvedenému rozdílu mohlo dojít na základě skryté vady, která nemusela být prokazatelná. Z naměřených hodnot je také patrné, že při nižší hustotě dřeva byla větší hloubka vrtu. Dřevěný zkušební vzorek tedy lépe odolával vniknutí vrtáku v př́ípadě, že hustota tělesa byla vyšší. Výše uvedené fakty byly zaznamenány ve formě grafu, viz Obr. 5. Všechny vrty byly provedeny na první stupeň na Kučerově vrtačce, kterému odpovídá 
25 otáček. Na základě dřivější studie nebylo možné zvýšit nastavení stupně Kučerovy vrtačky, ovšem první stupeň by měl být dostačujícím faktorem výzkumu.

\section{ZÁVĚR}

V závěru příspěvku je možné konstatovat, že poznání v rámci vlivu hustoty na hloubku vrtů bylo důležitým zjištěním pro další plánovaný výzkum. Ploché vrtáky, které byly použity v této fázi se jeví jako nejvhodnější řešení, jelikož jejich opotřebení je minimální a nedochází k mechanickému poškození vrtáku. V následujících krocích výzkumu je $\mathrm{v}$ plánu více vlhkostních prostředí docílených pomocí klimakomory $\mathrm{v}$ míře, kterou toto zařízení nabídne. Naměřené hodnoty budou dále porovnány s dosaženou pevností u pevnostních stanovení. $\mathrm{V}$ případě, že naměřené výsledky nebudou mít kolísavé hodnoty, mohlo by dojít k vytvoření kalibračního vztahu, který by na základě hloubky vrtů Kučerovou vrtačkou mohl určit přibližnou pevnost dřeva a tím by výrazně tato metoda mohla umožnit další posun v diagnostice dřevěných konstrukcí.

\section{Poděkování}

Výsledky uvedené v článku byly získány v rámci řešení projektu. č. FAST-J-21-7510: Zefektivnění testování pomocí semi-destruktivní diagnostické metody.

\section{Použité zdroje}

[1] BLÁHA, Jiří a Michal KLOIBER. Diagnostické metody pro hodnocení dřevěných konstrukcí in situ. ASB [online]. Mendelova zemědělská a lesnická univerzita v Brně, 2008, 10. 12. 2008 [cit. 202111-27]. Dostupné z: https://www.asb-portal.cz/architektura/rodinne-domy/drevostavby/diagnostickemetody-pro-hodnoceni-drevenych-konstrukci-in-situ

[2] KLOIBER, Michal a Miloš DRDÁCKÝ. Diagnostika dřevěných konstrukcí. Praha: ČKAIT, 2015. Technická knižnice (ČKAIT). ISBN 978-80-87438-64-0.

[3] ČERNÝ, Pavel a Věra HEŘMÁNKOVÁ. Diagnostika dřevěných konstrukcí a metody pro hodnocení dřevěných prvků. TZB info [online]. VUT Brno, Fakulta stavební, 2021, 24. 5. 2021 [cit. 2021-1127]. Dostupné z: https://stavba.tzb-info.cz/drevene-konstrukce/22288-diagnostika-drevenychkonstrukci-a-metody-pro-hodnoceni-drevenych-prvku

[4] HEŘMÁNKOVÁ, Věra, Ondřej ANTON a Tereza KOMÁRKOVÁ. Závislost fyzikálních a mechanických vlastností konstrukčního smrkového dřeva na vlhkosti. TZB Ino. Brno, 2018. ISSN 1801- 4399.

[5] HORÁČEK, Petr. Fyzikální a mechanické vlastnosti dřeva I. Přeprac. vydání. Brno: Mendelova zemědělská a lesnická univerzita v Brně, 2008. ISBN 978-80-7375-169-2.

[6] ČERNÝ, P.; HALAMOVÁ, R.; HEŘMÁNKOVÁ, V. Verification of the Use of a Kučera Drill for Testing of Wood Properties. In Proceedings of the 22nd Conference on the Rehabilitation and Reconstruction of Buildings. Key Engineering Materials (print). Trans Tech Publications Ltd., 2021. p. 107-112. ISBN: 9783035737783. ISSN: 1013-9826. 